Aletria, Belo Horizonte, v. 28, n. 1, p. 269-272, 2018

\title{
SOUZA, Roberto Acízelo de (Org.). Na aurora da literatura brasileira: olhares portugueses e estrangeiros sobre o cânone literário nacional em formação (1805-1885). Rio de Janeiro: Caetés, 2017.
}

Eduardo da Silva de Freitas

Universidade do Estado do Rio de Janeiro, Rio de Janeiro, Rio de Janeiro / Brasil eduardosfreitas@gmail.com

Publicado pela Editora Caetés em 2017, Na aurora da literatura brasileira é mais uma contribuição de peso dada por Roberto Acízelo de Souza para os estudiosos da literatura brasileira, sobretudo para os que se dedicam às ideias que movimentavam a atividade literária no Brasil do Oitocentos. Trata-se de uma compilação de textos de escritores de outros países que, à época, se debruçaram, com graus variados de ênfase, sobre a questão da nacionalidade da literatura produzida nestas paragens tropicais.

O organizador, que, no ano de 2015, mereceu com justiça os prêmios da Academia Brasileira de Letras, da Associação Brasileira de Editoras Universitárias e o Jabuti pela antologia Do mito das musas à razão das letras: textos seminais para os estudos literários (século $V$ a.C. - Século XVIII), emprega toda sua diligência para pôr à disposição do público textos há muito não editados e outros sequer divulgados, encontrados pelo próprio Roberto Acízelo ao longo de suas investigações.

Já pela publicação de textos inéditos no Brasil, dos escritores hispano-americanos José Mármol Zavalera e Eduardo Perié, o livro deixa registrado seu valor e préstimo. O texto de Mármol, "Juventude progressista do Rio de Janeiro", de 1846, é típica peça tribunícia dedicada à literatura que costumava circular pelos jornais brasileiros do século XIX e testemunha não só a grande difusão de certas ideias a respeito da nacionalidade da literatura do Brasil, como também o calor com que o 
tema era debatido. Por sua vez, o "Literatura brasileira: seus elementos constitutivos", escrito pelo provavelmente argentino Eduardo Perié e publicado em 1885, é um esboço histórico da literatura brasileira em estilo sóbrio e, por assim dizer, escolar.

Além dessas novidades, Acízelo põe em circulação peças consideradas capitais para a compreensão das questões centrais à crítica, à historiografia e à literatura no século XIX, dentre as quais o famoso Resumo da história da literatura brasileira, de Jean-Ferdinand Denis. Essa obra crucial do francês, a que mais influenciou a visão dos brasileiros sobre a literatura naquela época, agora traduzida pelo próprio professor Acízelo, apenas se encontrava no livro Historiadores e críticos do romantismo: 1 - contribuição europeia, publicado há quase 40 anos, em 1978, por Guilhermino César.

Aliás, é de se destacar a relação do trabalho de Roberto Acízelo com o de Guilhermino César. O volume de $\mathrm{Na}$ aurora da literatura brasileira se justifica como retomada do projeto de Guilhermino, consolidado com o aparecimento do livro mencionado. Lembre-se que, em 2014, ao publicar os dois volumes de Historiografia da literatura brasileira, Roberto Acízelo declarava que seu projeto consistia em executar o plano de Guilhermino César de coligir os estudos inaugurais de autores brasileiros sobre a história da literatura do Brasil. Considerando a publicação atual, pode-se dizer que o procedimento do premiado organizador constitui não só homenagem à memória de seu predecessor, como também representa com profundidade, no seio dos estudos sobre a literatura, aquela ideia de tradição como continuidade, mencionada por Antonio Candido em sua Formação da literatura brasileira.

Essa continuidade, enquanto avanço, se manifesta em parte pela ampliação dos textos que recheiam as páginas da coletânea de Acízelo. Enquanto Historiadores e críticos do romantismo reunia obras ou excertos de oito autores, o $\mathrm{Na}$ aurora da literatura brasileira compila escritos de 22 autores. Não caberia aqui citar todos. Todavia, é de se ressaltar que dentre esses nomes acrescentados estão figuras mais conhecidas dos estudiosos, como os portugueses Teófilo Braga e Camilo Castelo Branco, ao lado de outras não tão recorrentes como de Richard Francis Burton ou de Adèle Toussaint-Samson, que compõem o número dos viajantes europeus que percorreram estas paragens no século XIX.

Além disso, o confronto dos textos de autores que aparecem nas duas edições revela diferenças que não devem passar despercebidas. Em 
primeiro lugar, Acízelo traz novas traduções dos textos, ora feitas por ele, ora, por outro colaborador. Não são propriamente reformulações profundas das traduções anteriores, mas apresentam outros exemplos de uso do registro culto da língua portuguesa, por vezes mais próximos dos costumes atuais.

Mais importantes, talvez, sejam o recorte e a apresentação dos textos. Os excertos são por vezes distintos daqueles oferecidos por Guilhermino César. São os casos das passagens destacadas do "Bosquejo da história e da poesia e língua portuguesa", de Almeida Garrett, do "De la littérature du midi de l'Europe", de Simonde de Sismondi, e do "Brasil Literário", de Ferdinand Wolf. Quanto aos dois primeiros, os fragmentos restringem-se a destacar as referências diretas aos escritores que vieram a integrar o cânone da literatura brasileira. Da obra de Wolf, recortam-se o prefácio e a introdução, em que o austríaco menciona algumas de suas fontes e propõe uma periodização para a história da literatura Brasil.

Sobre a apresentação dos textos, Acízelo lhes antepõe uma breve biografia dos autores, concentrando-se em suas atividades intelectuais. Junto a isso, acrescenta, por conta própria, títulos aos fragmentos. Assim o faz com os já mencionados fragmentos de Almeida Garrett e de Simonde de Sismondi, que intitula, respectivamente, "A literatura portuguesa e os engenhos brasileiros" e "O Brasil e o futuro das letras portuguesas". Esse é um expediente que dá, em boa medida, noção da intervenção e da interpretação que o organizador imprime ao material coligido.

De fato, não se deve perder de vista que o avanço de Roberto Acízelo na execução do projeto de Guilhermino César não se limita ao âmbito, por assim dizer, material. Não se trata de disputa, a questão não é trazer ao público mais textos do que seu antecessor. $\mathrm{O}$ acréscimo está, principalmente, na incorporação dos resultados de suas próprias pesquisas às linhas traçadas por Guilhermino César. Com isso, justapõe ao trabalho de seu antecessor sua própria contribuição.

Nesse sentido, o aporte conceitual trazido pelo organizador é significativo. Por meio de sua ideia central, registrada no subtítulo "olhares portugueses e estrangeiros sobre o cânone literário nacional em formação (1805-1885)", ele reconsidera a perspectiva anterior que unificava sob o rótulo de "contribuições europeias" tanto os escritos de autores portugueses, como os de autores de outros países do Velho Mundo. Se a designação "contribuição europeia” já não seria suficiente para designar o conjunto dos textos que recolhe, uma vez que entre eles 
estão também produções saídas das penas hispano-americanas, do ponto de vista de Acízelo, ela também deixaria escapar que, no século XIX, escritores brasileiros e portugueses se sentiam à vontade para comentar a produção de cada país. Quer dizer, do ponto de vista cultural, os autores portugueses percebiam certa proximidade de seus pares brasileiros que não era partilhada pelos escritores de outras nacionalidades. Por isso, a coletânea distribui os autores entre "portugueses e estrangeiros".

Longe de ser mero conceptismo, a interpretação de Roberto Acízelo capta diferentes formas de relação cultural entre os escritores de outros países e a produção literária no Brasil. O que se oferece é uma proposta de se pensar as ligações da literatura brasileira com os estudiosos de outros países de maneira mais ampla do que a partir da oposição Europa-Brasil. Agora, não só o cenário é mais amplo, na medida em que abriga as investidas de alguns interessados oriundos da própria América, como também as conexões são mais complexas, já que há um elemento cultural que se mostra irredutível a fatores geográficos.

O livro ainda é enriquecido com inúmeras anotações que permitem ao leitor recuperar os sentidos dos usos linguísticos, que por vezes soam estranhos aos hábitos contemporâneos, entender as referências tanto às personalidades e acontecimentos referidos nos textos, e se familiarizar com o contexto histórico da produção de cada texto. Efetivamente, Roberto Acízelo de Souza alcançou seu objetivo de disponibilizar aos estudiosos uma "edição criteriosa e anotada" de textos tão importantes sobre a literatura brasileira.

Recebido em: 31 de janeiro de 2018. Aprovado em: 1o de março de 2018. 